\title{
DINAMIKA KONSEPTUALISASI \\ PENDIDIKAN ILMU PENGETAHUAN SOSIAL (PIPS) DAN PENDIDIKAN KEWARGANEGARAAN (PKn) \\ PADA PENDIDIKAN DASAR DAN MENENGAH \\ (Suatu Telaah Collective Mindset dalam Ranah Historis-Epistemologis)
}

\author{
Udin Saripudin Winataputra (udin@ut.ac.id) \\ FKIP Universitas Terbuka \\ Sumanah Saripudin \\ UPBJJ-UT Bogor
}

\begin{abstract}
Generally, the conceptual framework of social studies in United States and in Indonesia includes concept and praxis of education in democracy which are organised in a form of (1) civic/citizenship education as one of the dimensions of goals, content, and processes of social studies; and (2) social studies education. Basically, education in democracy can also be deemed as a subsystem of social studies education, and social studies education. However, as a subsystem of education in democracy civic educationt has shown its uniqueness i.e. it sinergically focussed on the development of individual's potentials to become smart and good citizens. Along the line of the development of the ideals, instrumenst, and praxis of democracy civic/citizenship education has become the academic endeavour, which then is generally called as civic education or citizenship education.
\end{abstract}

Keywords: social studies, citizenship education, civics, social studies education democracy education, education for democratic citizenship.

Artikel ini mencoba mencari jawaban atas pertanyaan Bagaimana dinamika pemikiran tentang Pendidikan IPS dan PKn dalam konteks perubahan mindset? Jawaban tersebut sangat diperlulan sebagai salah satu langkah strategis dalam mengkaji arah pengembangan pendidikan IPS untuk pendidikan dasar dan menengah. Dalam konteks permasalahan tersebut ada beberapa alasan yang perlu dikemukakan. Pertama, sampai saat ini konseptualisasi pendidikan IPS untuk pendidikan dasar dan menengah masih belum solid karena belum tersosialisasikannya kerangka pikir tentang integrated social studies baik di lingkungan pengembang kurikulum maupun praktisi pendidikan. Kedua, secara konseptual kini semakin kuat adanya dorongan untuk menerapkan pendekatan konstruktivistik, ko-konstruktivistik, dan sosial-kultural dalam pendidikan persekolahan. Ketiga, dalam Undang-Undang RI No 20 Tahun 2003 tentang Sistem Pendidikan Nasional (Sisdiknas) secara eksplisit diterapkannya pripsip pendidikan sebagai proses pembudayaan dan pemberdayaan, pendidikan yang demokratis dan berkeadilan, pendidikan multimakna dan pendidikan dengan keteladanan, pembangunan kemauan, dan pengembangan kreativitas. Keempat, adanya komitmen untuk meningkatkan kualitas pendidikan melalui penerapan berbagai inovasi seperti kurikulum berbasis kompetensi, pembelajaran yang demokratis, pembelajaran kontekstual, dan pengembangan nilai iman dan taqwa, budi pekerti, dan karakter bangsa yang dalam sepuluh tahun terakhir ini sudah diujicobakan secara nasional. 
Berkaitan dengan semua alasan tersebut di atas, dirasakan perlu untuk menggali, mengkaji, dan merumuskan berbagai alternatif pendekatan dan strategi pembelajaran IPS yang secara paradigmatik potensial untuk mewadahi berbagai esensi inovasi dalam praksis pendidikan IPS. Untuk itu dalam artikel ini dibahas butir-butir mengenai: Perkembangan Pemikiran IPS secara Umum, Konsep IPS Mengacu pada UU No 20 tahun 2003, Paradigma Pembelajaran IPS Untuk Pendidikan Dasar dan Menengah, dan Tantangan Pendidikan IPS ke Depan

\section{Perkembangan Pemikiran tentang Pendidikan IPS}

Secara konseptual perkembangan pendidikan IPS di Indonesia tidak bisa dipisahkan dari perkembangan pemikiran Social Studies yang berkembang secara universal. Sebagai pilar historisepistemologis social studies pertama, berupa suatu definisi akademik tentang social studies, telah dipancangkan oleh Edgar Bruce Wesley pada tahun 1937 (Barr,Barth, \& Shermis,1977:1-2) yaitu ... The Social Studies are the social sciences simplified for pedagogical purposes. Maksudnya, bahwa the Social Studies merupakan ilmu-ilmu sosial yang disederhanakan untuk tujuan pendidikan. Pengertian ini kemudian dibakukan dalam The United States of Education's Standard Terminology for Curriculum and Instruction (Barr et al,1977:2) sebagai berikut. The social studies comprised of those aspects of history, economics, political science, sociology, anthropology, psychology, geography, and philosophy which in practice are selected for instructional purposes in schools and colleges. Artinya, bahwa social studies berisikan aspek-aspek ilmu sejarah, ilmu ekonomi, ilmu politik, sosiologi , antropolgi, psikologi, ilmu geografi, dan filsafat, yang dalam praktek diseleksi untuk tujuan pembelajaran di sekolah dan di perguruan tinggi.

Pengertian awal social studies tersebut menyiratkan: pertama, social studies merupakan disiplin turunan dari ilmu-ilmu social atau menurut Welton dan Mallan (1988:14) sebagai an offspring of the social sciences; kedua, disiplin ini dikembangkan untuk memenuhi tujuan pendidikan/pembelajaran, baik pada tingkat persekolahan maupun tingkat pendidikan tinggi; dan ketiga, aspek-aspek dari masing-masing disiplin ilmu sosial itu perlu diseleksi sesuai dengan tujuan tersebut.

Dalam perjalanannya ternyata bidang social studies ini didera oleh masalah ketakmenetuan, yang oleh pionir social studies Edgar Bruce Wesley (dalam Barr et al,1978:iv) dikemukakan bahwa The field of social studies has long suffered from conflicting definition, an overlapping functions, and a confusion of philosophies". Keadaan itu diniliai telah menimbulkan "uncertainties; ... perpetuated indecision; ... hindered unification; ... and delayed progress. Keadaan yang ditandai dengan ketakmenentuan, ketakberkeputusan, ketakbersatuan, dan ketakmajuan tersebut dirasakan terutama pada periode 1940-1970-an. Pada tahap itu, seperti digambarkan oleh Barr et al, (1977:35-46), social studies menjalani periode yang sangat sulit.

Pada periode 1940-1950-an ia mendapat serangan hampir dari segala penjuru, yang pada dasarnya berkisar pada pertanyaan mesti tidaknya "social studies" menanamkan nilai dan sikap demokrasi kepada para pemuda. Persoalan itu tumbuh sebagai salah satu dampak dari perang sipil yang berkepanjangan, yang pada gilirannya melahirkan tuntutan bagi sekolah untuk mengajarkan pengetahuan, keterampilan, dan sikap yang diperlukan untuk berpartisipasi dalam masyarakat yang demokratis. Tuntutan tersebut telah mendorong muculnya upaya pemberian tekanan pada pentingnya pengajaran sejarah, berupa fakta-fakta sejarah yang perlu mendapat perhatian; kelembagaan pemerintahan Amerika; dan analisis rinci mengenai Konstitusi Amerika. Pada saat itu proses pembelajarannya sangat kuat menekankan pada mata pelajaran sosial yang terpisah-pisah, memorisasi informasi faktual, dan transmisi secara tidak kritis dari nilai-nilai budaya terpilih. 
Pada dasawarsa 1960-an , timbul suatu gerakan akademis yang mendasar dalam pendidikan, yang secara khusus dapat dipandang sebagai suatu revolusi dalam social studies, yang dipelopori oleh para sejarahwan dan ahli ilmu-ilmu sosial. Kedua kelompok ilmuwan tersebut nampaknya terpikat oleh social studies, antara lain karena pada saat itu pemerintah Federal Amerika menyediakan dana yang sangat besar untuk pengembangan kurikulum. Dengan dukungan dana tersebut para ahli dari berbagai disiplin bekerjasama untuk mengembangkan proyek kurikulum dan memproduksi bahan belajar innovatif dan menantang dalam skala yang besar. Gerakan akademis tersebut dikenal sebagai gerakan the new social studies. Namun demikian sampai dasawarsa 1970an ternyata gagasan untuk mendapatkan the new social studies ini belum menjadi kenyataan penuh. Isu yang terus menerpa social studies sampai pada saat itu adalah mengenai perlu tidaknya indoktrinasi, tujuan pembelajaran yang saling bertentangan, dan pertikaian mengenai isi pembelajaran.

Jika dilihat secara keseluruhan dalam periode 1940-1960, seperti ditegaskan oleh Barr et al (1977:36) yang sangat menonjol terjadi, adalah terjadinya tarik menarik antara dua visi social studies. Di satu pihak, adanya gerakan untuk mengintegrasikan berbagai disiplin ilmu sosial untuk tujuan citizenship education yang terus bergulir sampai mencapai tahap yang lebih canggih. Di lain pihak, terus bergulirnya gerakan pemisahan berbagai disiplin ilmu sosial yang cenderung memperlemah konsepsi social studies education. Hal tersebut antara lain merupakan dampak dari berbagai penelitian yang dirancang untuk mempengaruhi kurikulum sekolah, terutama yang berkenaan dengan pengertian dan sikap siswa. Selain itu, hal tersebut juga sebagai pengaruh dari opini publik yang berkaitan dengan dampak Perang Dunia II, Perang Dingin, dan Perang Korea, serta kritik publik terhadap kenyataan belum terwujudnya gagasan John Dewey tentang pengembangan kemampuan berpikir kritis dalam praktek pendidikan persekolahan.

Pada tahun 1955, seperti diungkapkan oleh Barr et al (1977:37) sesungguhnya telah terjadi terobosan yang besar berupa inovasi Maurice Hunt dan Lawrence Metcalf yang mencoba melihat cara baru dalam pengintegrasian pengetahuan dan keterampilan ilmu sosial untuk tujuan citizenship education. Dikemukakan bahwa program social studies di sekolah seyogyanya diorganisasikan bukan dalam bentuk pembelajaran ilmu sosial yang terpisah-pisah, tetapi diorientasikan kepada closed areas atau masalah-masalah yang tabu dalam masyarakat, seperti isu tentang seks, patriotisme, ras dan lain-lain yang biasanya penuh dengan prasangka, ketidaktahuan, mitos, dan kontroversi untuk diubah ke arah yang bersifat refleksi rasional. Dengan cara itu social studies mulai diarahkan kepada upaya guna melatih para siswa untuk dapat mengambil keputusan mengenai masalah-masalah publik. Disiplin ilmu-ilmu sosial diakui sangat berguna dalam memberikan fakta yang benar, dan teori, serta prinsip yang dapat digunakan dalam proses pengambilan keputusan. Kecenderungan social studies untuk melatih keterampilan "reflective thinking" ini, demikian ditekankan oleh Barr et al (1977:37) diperkuat oleh gagasan Shirley Engle yang pada tahun 1960 menerbitkan buku Decision Making: The Heart of Social Science Instruction yang secara mendasar dan tegas merefleksikan gagasan John Dewey tentang pendidikan berpikir kritis.

Tekanan perubahan lain yang juga cukup dahsyat muncul pada tahun 1957 dalam bentuk upaya komprehensif untuk mereformasi social studies. Yang menjadi pemicu dan pemacu perubahan tersebut adalah keberhasilan Rusia meluncurkan Sputnik yang telah membuat Amerika menjadi panik dan merasa jauh tertinggal dari Rusia, dan dipublikasikannya hasil penelitian dua orang dosen Purdue University, H.H,Remmers dan D.H. Radles yang dikenal dengan Purdue Opinion Poll. Penelitian dengan sampel anak usia sekolah ini menyimpulkan hal-hal sebagai berikut. Pertama, hanya $35 \%$ dari pemuda yang percaya bahwa surat kabar perlu diijinkan untuk menerbitkan apa saja 
yang diinginkannya; kedua, sebesar 34\% percaya bahwa pemerintah perlu melarang sebagian orang untuk berbicara; ketiga, sebesar $26 \%$ percaya bahwa polisi perlu diijinkan untuk menggeledah rumah seseorang tanpa jaminan; keempat, sebesar 25\% merasakan bahwa beberapa kelompok tidak perlu diijinkan mengadakan pertemuan. Hasil penelitian tersebut dinilai sebagai salah satu kegagalan dari social studies yang bersifat content-centered dengan dominasi pendekatan expository, yang sekaligus memberi petunjuk perlunya perubahan pembelajaran social studies menjadi pembelajaran yang berorientasi kepada the integrated, reflective inquiry, and problem-centered (Barr et al,1977:4142). Kesemua itu telah memperkuat munculnya gerakan the new social studies.

Gerakan the new social studies yang dapat dipandang sebagai pilar kedua dalam perkembangan epistemologi social studies pada tahun 1960-an itu, juga bertolak dari kesimpulan bahwa social studies sebelumnya dinilai sangat tidak efektif dalam mengajarkan substansi dan mempengaruhi perubahan sikap siswa. Oleh karena itu para ilmuwan, dalam hal ini sejarahwan dan ahli ilmu-ilmu sosial bersatu padu untuk bergerak meningkatkan social studies kepada taraf higher level of intellectual pursuit (Barr et al,1977:42) yakni mempelajari ilmu sosial secara mendasar. Dengan orientasi baru tersebut, maka dimulailah era baru pembelajaran social science education.

Gerakan tersebut dipacu lebih kuat oleh pemikiran Jerome Bruner dengan bukunya The Process of Education yang dengan tegas berargumentasi bahwa any subject can be taught effectively in some intellectually honest form to any child at any stage of development (Barr et al, 1977:43). Pandangan ini ternyata sangat mempengaruhi pikiran dan sikap para sejarahwan dan ahli ilmu sosial, dan kemudian mereka berargumentasi mengapa harus bersusah payah mengembangkan social studies, bila memang konsep, generalisasi, teori, dan metode, serta modus disiplin akademis dapat diajarkan kepada anak dalam berbagai tingkat usia.

Atas dasar postulat yang diilhami teori Bruner tersebut, pada akhirnya para sejarahwan, ahli ilmu sosial, dan pendidik sepakat untuk melakukan reformasi social studies dengan menggunakan cara yang berbeda dari sebelumnya. Pendekatan tersebut ditempuh melalui pengembangan kurikulum sekolah. Sekelompok pendidik, ahli psikologi, dan ahli ilmu sosial secara bersama-sama mengembangkan bahan belajar berdasarkan temuan penelitian dan teori belajar, kemudian diujicobakan di lapangan, selanjutnya direvisi, dan pada akhirnya disebarluaskan untuk digunakan dalam skala yang lebih besar dalam dunia persekolahan. Pada era itu tercatat lebih dari 50 proyek pengembangan kurikulum dan bahan belajar social studies, termasuk di dalamnya proyek yang mencoba merintis pengintegrasian social studies untuk tujuan citizenship education..

Seperti direkam oleh Barr et al (1977:43-44) dari berbagai penelitian dan pengembangan itu para ahli menemukan kenyataan betapa sukarnya mengoperasionalkan teori Bruner tersebut. Berkaitan dengan hal itu, dalam tulisannya The Concept of the Structure of a Discipline, Joseph J. Schwab menegaskan bahwa ... there are real and genuine difference among different phenomena . Oleh karena itu setiap disiplin bersifat unik, karena itu seyogyanya hal itu diajarkan secara terpisah. Pandangan ini terus bergulir dan seterusnya mendorong timbulnya upaya untuk mentransformasikan social studies ke dalam social science dan mengajarkannya sebagai disiplin akademis yang terpisah. Gerakan inilah yang mendorong berdirinya The Social Science Education Consortium (SSEC), yang kemudian menerbitkan bukunya yang pertama Concepts and Structures in the New Social Studies Curriculum. Para pakar SSEC sepakat bahwa struktur disiplin akademis memiliki dua komponen, yakni: ...the fundamental concepts and generalizations of a discipline, and the methods, procedures, and models necessary to develop and revise these fundamentals". Hal ini memberi implikasi pada bahan belajar the new social studies yang harus dirancang untuk membelajarkan 
siswa guna menguasai concepts and the methods of inquiry used by historians and social scientists to generate knowledge (Barr et al, 1977:45).

Pada akhir dasawarsa 1960-an tercatat (Barr, et al,1977:45) adanya perubahan orientasi pada disiplin akademik yang terpisah-pisah ke suatu upaya untuk mencari hubungan interdisipliner. Untuk ini The Social Studies Curriculum Center at Syracuse mengidentifikasi 34 konsep dasar yang digali dari sejumlah disiplin ilmu sosial yang dinilai perlu untuk diajarkan di sekolah. Hal ini memberi petunjuk terjadinya rekonsiliasi para ahli ilmu sosial dengan kelompok yang menekankan "social studies" pada "citizenship education". Pada masa itulah Paul R.Hanna merintis pengembangan kurikulum yang bertolak dari "basic human activities" dan berhasil menghimpun lebih dari 3000 generalisasi yang relevan, yang digali dari berbagai disiplin ilmu sosial.

Pada dasawarsa 1970-an (Barr et al: 1977:46) terjadi pertumbuhan social studies yang serupa dengan perkembangan sebelumnya dengan hasilnya hampir semua projek kurikulum menitikberatkan pada inquiry process, decision making, value questions, and student-oriented problems. Namun demikian hasil studi mengenai kurikulum dan pembelajaran tersebut ternyata sangat mengejutkan. Para ahli ternyata mendapatkan kesimpulan yang sama yakni, terlepas dari upaya terbaik dari para pendidik dan besarnya biaya yang dikeluarkan oleh pemerintah, ternyata ... the schools had not improved - ternyata belum banyak terjadi perubahan di sekolah (Barr et al,1977:48).

Perkembangan selanjutnya, yakni antara tahun 1976-1983, seperti dikemukakan oleh Stanley (1985:310) ... social studies education was a field of numerous competing definitions and rationales. Hal tersebut memang sejalan dengan apa yang dilihat dan dialami oleh Wesley (dalam Barr, Barth, \& Shermis,1978:iv) yang telah mencatat penggunaan istilah social studies sebagai social sciences, social service, socialism, radical left-wing thinking, social reform, anti history, a unification of social subjects, a field, a federation, an integrated curriculum, a pro-child reform, and a curriculum innovation. Terlepas dari adanya aneka penggunaan pengertian tersebut, ditegaskan bahwa The heart of the social studies is relationship; relationships premarily between and among human beings. Sedangkan jika dilihat dari visi, missi, dan strateginya, Barr et al (1978:17-19) social studies dapat dikembangkan dalam tiga tradisi, yakni Social Studies Taught as Citizenship Transmission, Social Studies Taught as Social Science, and Social Studies Taught as Reflective Inquiry. Sedangkan definisi baru yang diajukan yang dapat dipandang sebagai pilar ketiga epistemologi social studies adalah sebagai berikut.

Social Studies is an integration of social sciences and hummanities for the purposes of instruction in citizenship education. We emphasize 'integration', for social studies is the only field which deliberately attempts to draw upon, in an integrated fashion, the data of the social sceinces and the insights of hummanities. We emphasize 'citizenship', for social studies', despite the difference in orientation, outlook, purpose, and methods of teachers, is almost universally perceived as preparation for citizenship in a democracy (Barr et al,1978:18)-(cetak tebal dari penulis)

Definisi social studies dan pengindentifikasian social studies ke dalam tiga tradisi pedagogis tersebut di atas dapat dianggap sebagai pilar utama dari social studies pada dasawarsa 1970-an. Dalam definisi tersebut tersurat dan tersirat beberapa hal. Pertama, social studies merupakan suatu sistem; kedua, missi utama social studies adalah pendidikan kewarganegaraan dalam suatu masyarakat yang demokratis; ketiga, sumber utama konten social studies adalah social sciences dan 
hummanities, dan keempat, dalam upaya penyiapan warga negara yang demokratis terbuka kemungkinan perbedaan dalam orientasi, dan strategi pembelajaran. Jika dilihat lebih jauh, adanya variasi tiga tradisi social studies menyiratkan bahwa dimanapun terbuka kemungkinan untuk mengembangkan social studies atas dasar salah satu tradisi atau kombinasi dua atau semua tradisi. Masing-masing tradisi tersebut secara singkat dapat dijelaskan sebagai berikut.

Tradisi pertama, Social Studies Taught as Citizenship Transmission merujuk pada suatu modus pembelajaran sosial yang bertujuan untuk mengembangkan warganegara yang baik, yang ditandai oleh ciri-ciri: ....conforms to certain accepted parctices, hold particular beliefs, is loyal to certain values, participates in certain activities, and conforms to norms which are often local in character (Barr et al,1978:22). Oleh karena itu tujuan dari tradisi ini adalah mengembangkan a reasoned patriotism; a basic understanding and appreciation of (American) values, institution, and practices; personal identity and integrity and responsible citizenship; understanding and appreciation of the (American )heritage; active democratic participation; an awareness of social problems, and desirable ideals, attitudes, and behavioral skills (Barr et al,1978:47). Dalam ungkapan lain, tradisi ini bertujuan untuk mengembangkan karakter warganegara yang baik sesuai dengan nilai dan norma yang telah diterima secara baku dalam suatu negara.

Tradisi kedua, Social Studies Taught as Social Science merupakan modus pembelajaran sosial yang juga mengembangkan karakter warganegara yang baik, yang ditandai oleh penguasaan mode of thinking from social science disiplines; that this mode of thinking is generalizable; and having learned it he will understand properly, appreciate deeply, infer carefully, and conclude logically (Barr et al,1978:23-24). Hal tersebut dilandasi oleh kepercayaan bahwa ...if a student acquires the habit of mind and the thinking patterns associated with a particular social science discipline, he will become more discriminating, make better personal as well as social policy decisions, and ultimately understand the structure and the process of our society (Barr, et al,1978:71). Dengan kata lain tradisi ini memusatkan perhatian pada upaya pengembangan karakter warganegara yang baik, yang antara lain ditandai oleh kemampuannya dalam melihat dan mengatasi masalah-maslah sosial dan personal dengan menggunakan visi dan cara kerja para ilmuwan sosial.

Tradisi ketiga, Social Studies Taught as Reflective Inquiry merupakan modus pembelajaran sosial yang menekankan pada hal yang juga sama, yakni pengembangan warganegara yang baik dengan kriteria yang berbeda, yaitu dilihat dari kemampuannya ... to engage in a continual process of clarifying process of clarifying their own value structure (Barr, et al,1978:27). Oleh karena itu tujuan utama dari radisi ini adalah ... the enhancement of the students' decision making abilities, for decision making is the most important requirement of citizenship in a political democracy (Barr, et al, 1978:111). Dengan kata lain tradisi ini memusatkan perhatian pada pengembangan karakter warganegara yang baik dengan ciri pokonya mampu mengambil keputusan. Selain ketiga tradisi tersebut muncul juga dua tradisi baru yakni Social studies as social critics dan social studies as child development. Namun kedua tradisi baru tersebut sesungguhnya masih bisa diakomodasikan ke dalam tiga tradisi utama yakni social critics dapat dimasukkan ke dalam tradisi social science dan child development bisa dimasukkan ke dalam tradisi citizenship transmission.

Pada dasawarsa 1980-an perkembangan social studies ditandai oleh lahirnya dua dokumen akademis yakni Report of the National Council for Social Studies Task Force on Scope and Sequence yang berjudul In Search of a Scope and Sequence for Social Studies (NCSS,1983) dan A Report of the Curriculum Task Force of the National Commission on Social Studies in the School yang berjudul Charting A Course: Social Studies for the 21 $1^{\text {st }}$ Century (NCSS,1989). Kedua dokumen tersebut dapat dipandang sebagai pilar epistemologis social studies keempat dan kelima. 
Laporan pertama menghasilkan definisi, tujuan, lingkup, dan urutan materi mulai dari Kindergarten sampai dengan kelas XII; rincian democratic beliefs and values; dan rincian Skills in the Social Studies Curriculum. Definisi Social Studies yang diajukan adalah sebagai berikut.

Social Studies is a basic subject of the K-12 curriculum that (1) derives its goals from the nature of citizenship in a democratic society that is closely linked to other nations and peoples of the world; (2) draw its content primarily from history, the social sciences, and in some respects from the hummanities and science; and (3) is taught in ways that reflect an awareness of the personal, social, and cultural experiences and developmental level of learners (NCSS,1983:251)

Sedangkan tujuannya dirumuskan sebagai berikut.

Social Studies programs have a responsibility to prepare young people to identify, understand, and work to solve problems that face our increasingly diversed nation and interdependence world. Over the past several decades, the professional consensus has been that such programs ought to include goals in the broad areas of knowledge, democratic values, and skills. Program that combine the acquisition of knowledge and skills with the application of democratic values to life through social participation present an ideal balance in social studies. It is essential that these major goals be viewed as equally important. The relationship among knowledge, values, and skills is one of mutual support (NCSS,1983:251)

Jika dilihat dari definisi dan tujuannya, "social studies" menurut versi NCSS 1983 tersebut menyuratkan dan menyiratkan beberapa hal penting.. Pertama, social studies merupakan mata pelajaran dasar di seluruh jenjang pendidikan persekolahan. Kedua, tujuan utama mata pelajaran ini ialah mengembangkan siswa untuk menjadi warganegara yang memiliki pengetahuan, nilai, sikap, dan keterampilan yang memadai untuk berperan serta dalam kehidupan demokrasi' Ketiga, konten pelajarannya digali dan diselekasi dari sejarah dan ilmu sosial, serta dalam banyak hal dari humaniora dan sains. Keempat, pembelajarannya menggunakan cara-cara yang membangkitkan kesadaran pribadi, kemasyarakatan, pengalaman budaya, dan pengalaman pribadi siswa. Kesemua itu mencerminkan visi, missi, dan strategi yang senapas dengan apa yang telah diajukan oleh Barr dkk (1978) yang penulis pandang sebagai pilar ketiga social studies itu, yang selanjutnya dikokohkan menjadi pilar keempat. Hal tersebut sekaligus mencerminkan bahwa pada dasawarsa 1980-an telah terjadi kristalisasi pemikiran social studies yang lebih solid dan telah mencairnya masalah ketakmenentuan, ketakberkeputusan, ketakbersatuan, dan ketakmajuan dalam perkembangan social studies pada 4-5 dasawarsa sebelumnya.

Kemajuan tersebut tidaklah bebas dari kritik, malah muncul berbagai kritik yang dikemukakan dengan tegas (NCSS,1983:263-273). Kritik pertama dikemukakan oleh R.Freeman Butts yang menilai menilai tujuan social studies sebagai It does more than pay lip service to the citizenship goals". Sedangkan James P.Shaver mengingatkan bahwa ...the difficulties in preparing an adequate scope and sequence statement are great, untuk itu, ia katakan, diperlukan ... sufficient funding to do the job properly. Di lain pihak, Ronald G.Helms, melihat bahwa lingkup dan urutan bahan tersebut hanya diperlukan oleh School District yang memang ...have neither time nor resources to develop good alternatives. Sementara itu Geraldine Hellman-Rosenthal mengingatkan 
betapa telah berkembangnya penelitian psikologi tentang perkembangan anak. Karena itu, ia mengatakan : It would seem that any attempt to provide guidance on social studies scope and sequence should reflect these development. Di lain pihak, Jesus Garcia menilai Laporan tersebut sebagai ... document appears to be a reaction rather than a statement on the social studies. Ia lebih lanjut menilai bahwa Laporan tersebut sebagai ... an important and timely document. Namun demikian, ditegaskannya bahwa dokumen tersebut seyogyanya ...not be labelled as final, fixed word on social studies curriculum, demikian dipertegas oleh Louis Grigar.

Dalam Laporan NCSS kedua, yang penulis pandang sebagai pilar epistemologis social studies kelima, yakni Charting A Course:.. tampak jelas upaya untuk mempertegas visi, missi, dan strategi "social studies" dalam Laporan pertama Scope and Sequence .... Menurut laporan tersebut, untuk abad ke 21, social studies curriculum" seyogyanya memiliki ciri-ciri menitikberatkan pada ... role of citizen in a democracy"; memberikan "... consistent and cummulative learning from Kindergarten through $12^{\text {th }}$ grade"; menuntut "... history and geography should provide matrix or framework for social studies; memusatkan kurkulum bukan hanya pada "...major civilization and societies; mengembangkan jaringan keterkaitan ilmu sosial dengan ... hummanities and the natural and physical sciences; menempatkan konten untuk tidak diperlakukan sebagai hal yang harusa diterima dan diingat; menuntuk penerapan proses belajar interaktif, seperti ... reading, writing, observing, debating, role-play or simulation, working with statistical data and using critical thinking skills; memanfaatkan berbagai media dan sumber; pemberian dukungan dari seluruh jajaran pengelola pendidikan; dan menempatkan essential knowledge dalam pembelajaran di setiap jenjang pendidikan persekolahan.

Sedangkan yang menjadi tujuan dari Social Studies Education adalah mengembangkan karakteristik warga negara sebagai berikut.

(1) Civic responsibility and active civic participation. (2) Perspective on their own life experiences so they see themselves as part of the larger human adventure in time and place. (3) A critical understanding of the history, geography, economic, political, and social institutions, traditions, and values of the United States as expressed in both their unity and diversity. (4) An understanding of other peoples and the unity and diversity of world history, geography, institutions, traditions and values. (5) Critical attitudes and analytical perspectives appropriate to analysis of the human condition (NCSS,1989:6).

Dilihat dari karakteristik dan tujuannya, social studies education atau social studies yang dipikirkan untuk abad ke 21 tampak masih menempatkan proses pendidikan kewarganegaraan atau citizenship education yakni pengembangan civic responsibility and active civic participation sebagai salah satu esensinya. Esensi yang lainnya adalah pengembangan kemampuan sosial yang berkenaan dengan visi tentang pengalaman hidupnya, pemahaman kritis terhadap ilmu-ilmu sosial, pemahaman manusia dalam konteks persatuan dalam perbedaan, dan analisis kritis terhadap keadaan kehidupan manusia. Hal ini mengadung arti lebih memantapkan pemikiran yang memang telah mengkristal sebelumnya, sebagaimana telah dikemukakan dalam dokumen NCSS (1983) tentang Scope and Sequence ....

Bagaimanakah selanjutnya perkembangan pemikiran mengenai "social studies tersebut? Pada tahun 1992, the Board of Directors of the National Council for the Social Studies mengadopsi visi terbaru mengenai social studies, yang kemudian diterbitkan dalam dokumen resmi NCSS pada 
tahun 1994 dengan judul Expectations of Excellence: Curriculum Standards for Social Studies. Dokumen ini nampaknya yang sedang mewarnai pemikiran dan praksis social studies di Amerika Serikat sampai dengan saat ini. Di dalam dokumen tersebut (NCSS, 1994:3) diadopsi pengertian social studies sebagai berikut.

Social studies is the integrated study of the social sciences and humanities to promote civic competence. Within the school program, social studies provide coordinated, systematic study drawing upon such disciplines as anthropology, archeology, economics, geography, history, law, philosophy, political science, psychology, religion, and sociology, as ell as appropriate content from the humanities, mathematics, and natural sciences. The primary purpose of social studies is to help young people develop the ability to make informed and reasoned decisions for the public good as citizens of a culturally diverse, democratic society in an interdependent world. (cetak tebal dari penulis.)

Secara esensial, pengertian di atas mengandung visi, missi dan strategi pendidikan social studies yang mengokohkan kristalisasi pemikiran yang lebih solid dan kohesif dari para pakar dan praktisi yang tergabung dalam NCSS, yang secara sosial akademik sangat berpengaruh di Amerika Serikat, yang juga biasanya memberi dampak yang signifikan terhadap pemikiran dan praksis dalam bidang itu di negara lain. Hal tersebut mengisyaratkan bahwa dalam dua dasawarsa terakhir, 1980 dan 1990-an, pemikiran mengenai "social studies" yang sebelumnya dilanda penyakit ketakmenentuan, ketakberkeputusan, ketakbersatuan, dan ketakmajuan, seperti telah dibahas pada awal bab ini, paling tidak secara konseptual telah dapat diatasi. Hal ini, penulis pikir, merupakan suatu kemajuan besar dalam epistemologi disiplin pendidikan social studies. Dengan demikian pula, dapat diperkirakan bahwa pemikiran tersebut akan banyak mewarnai pemikiran dan praksis pendidikan "social studies"di Amerika Serikat dan negara lainnya pada dasawarsa awal abad ke 21 sekarang.

Sebagai rambu-rambu dalam rangka mewujudkan visi, missi, dan strategi baru social studies tersebut, NCSS (1994) menggariskan hal-hal sebagai berikut:

Pertama, program "social studies" mempunyai tujuan pokok .....the promotion of civic competence - which is the knowledge, skills, and attitudes required of students to be able to assume 'the office of citizen' (as Thomas Jefferson called it) in our democratic republic (NCSS, 1994:3). Di sini, kembali ditegaskan bahwa pendidikan kewarganegaraan, yang secara tersurat dikatakan sebagai pengembangan civic competence atau kemampuan sebagai warga negara yang memerlukan pengetahuan, keterampilan, dan sikap untuk dapat berperanserta dalam kehidupan demokrasi. Walaupun demikian ditegaskan bahwa pengembangan civic competence itu bukanlah hanya menjadi tanggung jawab dari social studies. Yang dimaksudkan adalah, bahwa esensi tujuan tersebut lebih diutamakan dalam social studies daripada dalam bidang lain.

Kedua, program social studies dalam dunia pendidikan persekolahan, mulai dari pendidikan taman kanak-kanak sampai dengan pendidikan menengah, ditandai oleh keterpaduan ...knowledge, skills, and attitudes within and across disciplines (NCSS, 1994:3). Hal ini memberi dasar bahwa pendidikan social studies memiliki dua alternatif, yakni yang bersifat monodisipliner dan multidesipliner. Pada kelas-kelas rendah ditekankan pada "social studies" yang mengintegrasikan beberapa disiplin yang bertolak dari suatu tema tertentu, misalnya tema time, continuity, and change yang memungkinkan guru mengembangkan pengalaman belajar siswa yang melibatkan disiplin 
sejarah, sains, dan bahasa. Pada kelas-kelas lanjutan dan menengah, program social studies dapat diteruskan dengan pengintegrasian secara interdisipliner atau sering disebut secara intersisciplinary yang lebih luas; atau dengan menempatkan suatu disiplin sebagai titik tolak, kemudian dikaitkan dengan atau diperkaya dari materi disiplin lainnya, yang sering disebut secara cross-disciplinary atau lintas disipliner. Karena itu pendekatan monodisipliner yang dimungkinkan, bukanlah dalam arti pembelajaran suatu disiplin sosial secara soliter, misalnya hanya sejarah atau geografi saja. Hal itu dapat dipahami karena fenomena dan masalah sosial dalam kenyataannya tidak bisa dipisahkan, misalnya antara pemanasan global, timbulnya El Nino dan La Nina, perubahan musim (dimensi geografi), produktivitas pertanian, tingkat pendapatan petani, dan tingkat kesejahteraan (dimensi ekonomi), serta perlindungan hukum (dimensi politik).

Ketiga, program social studies dititikberatkan pada upaya membantu siswa dalam .....construct a knowledge base and attitudes srawn from academic disciplines as specialized ways of viewing reality (NCSS, 1994:4). Di sini siswa diperankan bukan sebagai penerima pengetahuan yang pasif, tetapi sebagai pembangun pengetahuan dan sikap yang aktif melalui cara pandang secara akademik terhadap realita. Nampaknya pandangan konstruktivisme yang menitikberatkan pada process of knowing akan menjadi salah satu pilar dari social studies pada abad ke 21 tersebut, menggeser pandangan behaviorisme yang mengasumsikan pengetahuan ada di luar diri manusia dan menempatkan siswa sebagai recipient dari pengetahuan.

Keempat, program social studies mencerminkan ....the changing nature of knowledge, fostering entirely new ang highly integrated approaches to resolving issues of significance to humanity (NCSS, 1994:5). Dengan begitu hakikat pengetahuan yang semula dilihat secara terkotakkotak, kini harus dilihat secara terpadu yang menuntut perlibatan berbagai disiplin.

Untuk dapat mencapai semua yang digagaskan mengenai social studies tersebut, dikemukakan adanya tiga strategi dasar yakni supporting the common good,... adopting common and multiple perspectives, and... applying knowledge, skills, and values to civic action. Hal tersebut menyangkut pada pengembangan democratic ideals, principles, and practices; pengembangan kemampuan siswa untuk dapat melihat masalah dari berbagai perspektif yaitu personal perspective, academic perspective, pluralist perspective, and global perspective; dan perwujudan pengetahuan pengetahuan, keterampilan, dan sikap dalam perilaku sebagai warganegara (NCSS, 1994:5-7). Perkembangan tersebut melukiskan bagaimana social studies pada dunia persekolahan telah menjadi dasar ontologi dari suatu sistem pengetahuan yang terpadu, yang secara epistemologis telah mengarungi suatu perjalanan pemikiran dalam kurun waktu 60 tahun lebih yang dimotori dan diwadahi oleh NCSS sejak wahun 1935. Pemikiran tersebut secara tersurat dan tersirat merentang dalam suatu kontinum gagasan social studies Edgar Bruce Wesley (1935) sampai ke gagasan social studies terbaru dari NCSS (1994).

Pemikiran mengenai social studies sebagaimana telah dibahas di atas, tercatat banyak mempengaruhi pemikiran dalam bidang itu di negara lain, termasuk pemikiran mengenai pendidikan ilmu pengetahuan sosial (IPS) dan pendidikan kewarganegaraan di Indonesia. Untuk menelusuri perkembangan pemikiran atau konsep pendidikan IPS di Indonesia secara historis epistemologis terasa sangat sukar karena dua alasan. Pertama di Indonesia belum ada lembaga profesional bidang pendidikan IPS setua dan sekuat pengaruh NCSS atau SSEC. Lembaga serupa yang dimiliki Indonesia, yakni HISPIPSI (Himpunan Sarjana pendidikan IPS Indonesia) usianya masih sangat muda dan produktivitas akademisnya masih belum optimal, karena masih terbatas pada pertemuan tahunan dan komunikasi antar anggota secara insidental. Kedua perkembangan kurikulum dan pembelajaran IPS sebagai ontologi ilmu pendidikan (disiplin) IPS sampai saat ini sangat tergantung 
pada pemikiran individual dan atau kelompok pakar yang ditugasi secara insidental untuk mengembangkan perangkat kurikulum IPS melalui Pusat pengembangan Kurikulum dan Sarana Pendidikan Balitbang Dikbud (Puskur). Pengaruh akademis dari komunitas ilmiah bidang ini terhadap pengembangan IPS tersebut sangatlah terbatas, sebatas yang tersalur melalui anggotanya yang kebetulan dilibatkan dalam berbagai kegiatan tersebut. Jadi sangat jauh berbeda dengan peranan dan kontribusi Social Studies Curriculum Task Force - nya NCSS, atau SSEC di Amerika Serikat. Oleh karena itu, perkembangan pemikiran mengenai pendidikan IPS di Indonesia akan ditelusuri dari alur perubahan kurikulum IPS dalam dunia persekolahan, dikaitkan dengan beberapa konten pertemuan ilmiah dan penelitian yang relevan dalam bidang itu, yang secara sporadis dapat dijangkau oleh penulis.

Istilah IPS (Ilmu Pengetahuan Sosial), untuk pertama kalinya muncul dalam Seminar Nasional tentang Civic Education tahun 1972 di Tawang Manggu Solo. Menurut Laporan Seminar tersebut (Panitia Seminar Nasional Civic Education, 1972:2, dalam Winataputra, 1978:42) ada tiga istilah yang muncul dan digunakan secara bertukar-pakai (interchangeable) yakni "pengetahuan sosial, studi sosial, dan ilmu pengetahuan sosial" yang diartikan sebagai suatu studi masalahmasalah sosial yang dipilih dan dikembangkan dengan menggunakan pendekatan interdisipliner dan bertujuan agar masalah-masalah sosial itu dapat dipahami siswa. Dengan demikian para siswa akan dapat menghadapi dan memecahkan masalah sosial sehari-hari. Pada saat itu, konsep IPS tersebut belum masuk ke dalam kurikulum sekolah, tetapi baru dalam wacana akademis yang muncul dalam Seminar tersebut. Kemunculan istilah tersebut bersamaan dengan munculnya istilah IPA (IImu Pengetahuan Alam) dalam wacana akademis pendidikan Sains. Pengertian IPS yang disepakati dalam Seminar tersebut dapat dianggap sebagai pilar pertama dalam perkembangan pemikiran tentang pendidikan IPS. Berbeda dengan pemunculan pengertian social studies dari Edgar Bruce Wesley dalam pertemuan pertama NCSS tahun 1937 yang segera dapat respon akademis secara meluas dan melahirkan kontroversi akademik, pemunculan pengertian IPS dengan mudah diterima dengan sedikit komentar.

Konsep IPS untuk pertama kalinya masuk de dalam dunia persekolahan terjadi pada tahun 1972-1973, yakni dalam Kurikulum Proyek Perintis Sekolah Pembangunan (PPSP) IKIP Bandung. Hal ini terjadi karena, barangkali kebetulan beberapa pakar yang menjadi pemikir dalam Seminar Civic Education di Tawang Manggu itu, seperti Achmad Sanusi, Noeman Somantri, Achmad Kosasih Djahiri, dan Dedih Suwardi berasal dari IKIP Bandung, dan pada pengambangan Kurikulum PPSP IKIP Bandung berperan sebagai anggota tim pengembang kurikulum tersebut. Dalam Kurikulum SD 8 tahun PPSP digunakan istilah "Pendidikan Kewargaan Negara/Studi Sosial" sebagai mata pelajaran sosial terpadu. Penggunaan garis miring nampaknya mengisyaratkan adanya pengaruh dari konsep pengajaran sosial yang walaupun tidak diberi label IPS, telah diadopsi dalam Kurikulum SD tahun 1968. Dalam Kurikulum tersebut digunakan istilah Pensisikan Kewargaan negara yang di dalamnya tercakup Sejarah Indonesia, Ilmu Bumi Indonesia, dan Civics yang diartikan sebagai Pengetahuan Kewargaan Negara. Oleh karena itu, dalam Kurikulum SD PPSP tersebut konsep IPS diartikan sama dengan Pendidikan Kewargaan Negara. Penggunaan istilah Studi Sosial nampaknya dipengaruhi oleh pemikiran atau penafsiran Achmad Sanusi yang pada tahun 1972 menerbitkan sebuah manuskrip berjudul "Studi Sosial: Pengantar Menuju Sekolah Komprehensif" yang isinya diwarnai oleh pemikiran Leonard Kenworthy (1970) dengan bukunya Teaching Social Studies.

Sedangkan dalam Kurikulum Sekolah Menengah 4 tahun, digunakan tiga istilah yakni (1) "Studi Sosial " sebagai mata pelajaran inti untuk semua siswa dan sebagai bendera untuk kelompok mata pelajaran sosial yang terdiri atas geografi, sejarah, dan ekonomi sebagai mata pelajaran major 
pada jurusan IPS; (2) "Pendidikan Kewargaan Negara" sebagai mata pelajaran inti bagi semua jurusan; dan (3) "Civics dan Hukum" sebagai mata pwlajaran major pada jurusan IPS (PPSP IKIP Bandung, 1973a, 1973b). Kurikulum PPSP tersebut dapat dianggap sebagai pilar kedua dalam perkembangan pemikiran tentang pendidikan IPS, yakni masuknya kesepakatan akademis tentang IPS ke dalam kurikulum sekolah. Pada tahap ini konsep pendidikan IPS diwujudkan dalam tiga bentuk yakni, (1) pendidikan IPS terintegrasi dengan nama Pendidikan Kewargaan Negara/Studi Sosial, (2) pendidikan IPS terpisah, dimana istilah IPS hanya digunakan sebagai konsep payung untuk mata pelajaran geografi, sejarah, dan ekonomi; dan (3) pendidikan kewargaan negara sebagai suatu bentuk pendidikan IPS khusus, yang dalam konsep tradisi social studies termasuk tradisi citizenship transmission (Barr, et al: 1978).

Konsep pendidikan IPS tersebut kemudian memberi inspirasi terhadap Kurikulum 1975, yang memang dalam banyak hal mengadopsi inovasi yang dicoba melalui Kurikulum PPSP. Di dalam Kurikulum 1975 pendidikan IPS menampilkan empaqt profil yakni : (1) Pendidikan Moral Pancasila menggantikan Pendidikan Kewargaan Negara sebagai suatu bentuk pendidikan IPS khusus yang mewadahi tradisi citizenship transmission; (2) pendidikan IPS terpadu untuk Sekolah Dasar; (3) pendidikan IPS terkonfederasi untuk SMP yang menempatkan IPS sebagai konsep payung yang menaungi mata palajaran geografi, sejarah, dan ekonomi koperasi; dan (4) pendidikan IPS terpisahpisah yang mencakup mata pelajaran sejarah, geografi, dan ekonomi untuk SMA, atau sejarah dan geografi untuk SPG (Dep. P dan K, 1975a; 1975b, 1975c; dan 1976). Konsep pendidikan IPS seperti itu tetap dipertqahankan dalam Kurikulum 1984, yang memang secara konseptual merupakan penyempurnaan dari Kurikulum 1975. Penyempurnaan yang dilakukan khususnya dalam aktualisasi materi yang disesuaikan dengan perkembangan baru dalam masing-masing disiplin, seperti masuknya Pedoman Penghayatan dan Pengamalan Pancasila (P4) sebagai materi pokok Pendidikan Moral Pancasila. Sedang konsep pendidikan IPS itu sendiri tidak mengalami perubahan yang mendasar.

Dengan berlakunya Undang-Undang No. 2/1989 tentang Sistim Pendidikan Nasional, dalam wacana pendidikan IPS muncul dua bahan kajian kurikuler pendidikan Pancasila dan pendidikan kewarganegaraan. Kemudian ketika ditetapkannya Kurikulum 1994 menggantikan kurikulum 1984, kedua bahan kajian tersebut dilembagakan menjadi satu pelajaran Pendidikan Pancasila dan Kewarganegaraan (PPKn). Secara konseptual mata pelajaran ini masih tetap merupakan bidang pendidikan IPS yang khusus mewadahi tradisi citizenship transmission dengan muatan utama butirbutir nilai Pancasila yang diorganisasikan dengan menggunakan pendekatan spiral of concept development ala Taba (Taba: 1967) dan expanding environment approach ala Hanna (Dufty, 1970) dengan bertitiktolak dari masing-masing sila Pancasila.

Di dalam Kurikulum 1994 mata pelajaran PPKn merupakan mata pelajaran sosial khusus yang wajib diikuti oleh semua siswa setiap jenjang pendidikan (SD,SLTP,SMU). Sedangkan mata pelajaran IPS diwujudkan dalam: pertama, pendidikan IPS terpadu di SD kelas III s/d kelas VI; kedua, pendidikan IPS terkonfederasi di SLTP yang mencakup materi geografi, sejarah, dan ekonomi kooperasi: dan ketiga, pendidikan IPS terpisah-pisah yang mirip dengan tradisi social studies taught as social science menurut Barr et al (1978). Di SMU ini bidang pendidikan IPS terpisah-pisah terdiri atas mata pelajaran Sejarah Nasional dan Sejarah Umum di kelas I dan II; Ekonomi dan Geografi di kelas I dan II; Sosiologi di kelas II; Sejarah Budaya di kelas III Program Bahasa; Ekonomi, Sosiologi, Tata Negara, dan Antropologi di kelas III Program IPS.

Dilihat dari tujuannya, setiap mata pelajaran sosial memiliki tujuan yang bervariasi. Mata pelajaran Sejarah Nasional dan Sejarah Umum bertujuan untuk "....menanamkan pemahaman 
tentang perkembangan masyarakat masa lampau hingga masa kini, menumbuhkan rasa kebangsaan dan cinta tanah air serta rasa bangga sebagai warga bangsa Indonesia, dan memperluas wawasan hubungan masyarakat antar bangsa di dunia" (Depdikbud, 1993: 23-24). Dimensi tujuan tersebut pada dasarnya mengandung esensi pendidikan kewarganegaraan atau tradisi "citizenship transmission" (Barr, et al: 1978). Mata pelajaran Ekonomi bertujuan untuk "....memberikan pengetahuan konsep-konsep dan teori sederhana dan menerapkannya dalam pemecahan masalahmasalah ekonomi yang dihadapinya secara kritis dan obyektif" (Depdikbud, 1993: 29). Sedang untuk Program IPS mata pelajaran Ekonomi ini bertujuan untuk "... memberikan bekal kepada siswa mengenal beberapa konsep dan teori ekonomi sederhana untuk menjelaskan fakta, peristiwa, dan masalah ekonomi yang dihadapi" (Depdikbud, 1993: 29). Dari rumusan tujuan tersebut dapat ditafsirkan bahwa tujuan pendidikan Ekonomi di SMU baik untuk program umum maupun untuk program IPS mengisyaratkan diterapkannya tradisi social studies taught as social science (Barr, et al: 1978).

Tradisi ini tampaknya diterapkan juga dalam mata pelajaran Sosiologi, Geografi, Tata Negara, Sejarah Budaya, dan Antropologi sebagaimana dapat dikaji dari masing-masing tujuannya. Mata pelajaran Sosiologi memiliki tujuan "...untuk memberikan kemampuan memahami secara kritis berbagai persoalan dalam kehidupan sehari-hari yang muncul seiring dengan perubahan masyarakat dan budaya, menanamkan kesadaran perlunya ketentuan masyarakat, dan mampu menempatkan diri dalam berbagai situasi sosial budaya sesuai dengan kedudukan, peran, norma, dan nilai sosial yang berlaku di masyarakat" (Depdikbud, 1993: 30). Sementara itu mata pelajaran Geografi memusatkan perhatian pada upaya "...untuk memberikan bekal kemampuan dan sikap rasional yang bertanggung jawab dalam menghadapi gejala alam dan kehidupan di muka bumi serta permasalahannya yang timbul akibat interaksi antara manusia dengan lingkungannya" (Depdikbud, 1993: 30). Sedangkan mata pelajaran Tata Negara menggariskan tujuan "...untuk meningkatkan kemampuan agar siswa memahami penyelenggaraan negara sesuai dengan tata kelembagaan negara, tata peradilan negara sesuai dengan tata kelembagaan negara, tata peradilan, sistim pemerintahan Negara RI maupun negara lain" (Depdikbud, 1993: 31).

Hal yang juga tampak sejalan terdapat dalam rumusan tujuan mata pelajaran Sejarah Budaya yang menggariskan tujuannya untuk “... menanamkan pengertian adanya keterkaitan perkembangan budaya masyarakat pada masa lampau, masa kini, dan masa mendatang sehingga siswa menyadari dan menghargai hasil dan nilai budaya pada masa lampau dan masa kini" (Depdikbud, 1993: 31). Demikian juga dalam tujuan mata pelajaran Antropologi yang dengan tegas diorientasikan pada upaya untuk “... memberikan pengetahuan mengenai proses terjadinya kebudayaan, pemanfaatan dan perwujudannya dalam kehidupan sehari-hari; menanamkan kesadaran perlunya menghargai nilai-nilai budaya suatu bangsa, terutama bangsa sendiri," dan pada akhirnya dimaksudkan juga untuk "... menanamkan kesadaran tentang peranan kebudayaan dalam perkembangan dan pembangunan masyarakat serta dampak perubahan kebudayaan terhadap kehidupan masyarakat" (Depdikbud, 1993: 33).

Bila disimak dari perkembangan pemikiran pendidikan IPS yang terwujudkan dalam Kurikulum sampai dengan dasawarsa 1990-an ini pendidikan IPS di Indonesia mempunyai dua konsep pendidikan IPS, yakni : pertama, pendidikan IPS yang diajarkan dalam tradisi citizenship transmission dalam bantuk mata pelajaran Pendidikan pancasila dan Kewarganegaraan dan Sejarah Nasional; kedua, pendidikan IPS yang diajarkan dalam tradisi "social science" dalam bentuk pendidikan IPS terpisah dari SMU, yang terkonfederasi di SLTP, dan yang terintegrasi di SD. 
Dilihat dari kajian konseptual para pakar Indonesia, dalam pembahasannya tentang "Perspektif Pendidikan Ilmu (Pengetahuan) Sosial", Sanusi (1998) menyinggung sedikit tentang pengajaran IPS di sekolah. Sanusi (1998: 222-227) melihat pengajaran IPS di sekolah cenderung menitikberatkan pada penguasaan hafalan; proses pembelajaran yang terpusat pada guru; terjadinya banyak miskonsepsi; situasi kesal yang membosankan siswa; ketidaklebihunggulan guru dari sumber lain; ketidakmutahiran sumber belajar yang ada; sistem ujian yang sentralistik; pencapaian tujuan kognitif yang 'mengulit-bawang'; rendahnya rasa percaya diri siswa sebagai akibat dari amat lunaknya isi pelajaran, kontradiksi materi dengan kenyataan, dominannya latihan berfikir tarap rendah, guru yang tidak tangguh, persepsi negatif dan prasangka buruk dari masyarakat terhadap kedudukan dan peran ilmu sosial dalam pembangunan masyarakat. Oleh karena itu Sanusi (1998) merekomendasikan perlunya reorientasi pengembangan yang mencakup peningkatan mutu SDM dalam hal ini guru agar lebih mampu mengembangkan kecerdasan siswa lebih optimal melalui variasi interaksi dan pemanfaatan media dan sumber belajar yang lebih menantang. Bersamaan itu pula diperlukan upaya peningkatan dukungan sarana dan prasarana serta insentif yang fair. Dalam dimensi konseptual, Sanusi (1998: 242-247) manyarankan perlunya batasan yang jelas menganai tujuan dan konten pendidikan ilmu sosial untuk berbagai jenjang pendidikan, termasuk di dalamnya pola pemilihan dan pengorganisasian tema-tema pembelajaran yang dinilai lebih esensial dan sesuai dengan kebutuhan dan tuntutan perubahan dalam masyarakat.

Dimensi konseptual mengenai pendidikan IPS tampaknya telah berulang kali dibahas dalam rangkaian pertemuan ilmiah yakni Pertemuan HISPIPSI pertama tahun 1989 di Bandung, Forum Komunikasi Pimpinan FPIPS di Yogyakarta tahun 1991, di Padang tahun 1992, di Ujung Pandang tahun 1993, Konvensi Pendidikan kedua di Medan tahun 1992. Salah satu materi yang selalu menjadi agenda pembahasan adalah mengenai konsep PIPS. Dalam pertemuan Ujung Pandang tahun 1993, M. Numan Somantri selaku pakar dan Ketua HISPIPSI (Somantri: 1993) kembali menegaskan adanya dua versi PIPS sebagaimana dirumuskan dalam Pertemuan Yogyakarta tahun 1991, sebagai berikut.

"Versi PIPS untuk Pendidikan Dasar dan Menengah:

PIPS adalah penyederhanaan, adaptasi dari disiplin ilmu-ilmu sosial dan humaniora, serta kegiatan dasar manusia, yang diorganisir dan disajikan secara ilmiah dan pedagogis/psikologis untuk tujuan pendidikan.

Versi PIPS untuk FPIPS dan Jurusan Pendidikan IPS-IKIP:

PIPS adalah seleksi dari disiplin ilmu-ilmu sosial dan humaniora serta kegiatan dasar manusia yang diorganisir dan disajikan secara ilmiah dan psikologis untuk tujuan pendidikan"

Kelihatannya HISPIPSI ingin mencoba menjernihkan pengertian PIPS dengan cara menggunakan label yang sama yakni PIPS tetapi dengan dua versi pengertian, yakni pengertian PIPS untuk pendidikan persekolahan dan untuk pendidikan tinggi untuk guru IPS di IKIP/STKIP/FKIP. Dari dua versi pengertian itu, yang membedakannya penulis pikir, dalam format sistim pangetahuannya. Untuk dunia persekolahan merupakan penyederhanaan, atau sama dengan gagasan Wesley (1937) dengan konsep social sciences simplified..., sedang untuk pendidikan guru IPS berupa seleksi. Namun rasanya perbedaannya tidak begitu jelas, kecuali seperti dikatakan oleh Somantri (1993: 8) dalam tingkat kesukarannya sesuai dengan jenjang pendidikan itu, yakni di dunia persekolahan disesuaikan dengan tingkat perkembangan anak, sedang di perguruan tinggi 
disesuaikan dengan taraf pendidikan tinggi. Penjelasan ini menurut penulis terkesan bersifat tautologis. Kedua versi pengertian PIPS tersebut masih dipertahankan sampai dalam Pertemuan Terbatas HISPISI di Universitas Terbuka Jakarta tahun 1998 (Somantri, 1998: 5-6), dan disepakati akan menjadi salah satu esensi dari position paper HISPIPSI tentang Disiplin PIPS yang akan diajukan kepada LIPI.

Jika dilihat dari pokok-pokok pikiran yang diajukan oleh Numan Somantri selaku Ketua HISPIPSI (Somantri, 1998) Position Paper itu akan menyajikan penegasan mengenai kedudukan PIPS sebagai synthetic discipline atau menurut Hartoonian (1992) sebagai integrated system of knowledge. Oleh karena itu, PIPS untuk tingkat perguruan tinggi pendidikan guru IPS, direkonseptualisasikan sebagai pendidikan disiplin ilmu sehingga menjadi Pendidikan Disiplin IImu Pengetahuan Sosial disingkat menjadi PDIPS. Dengan demikian kelihatannya HISPIPSI akan memegang dua konsep yakni konsep PIPS untuk dunia persekolahan, dan konsep PDIPS untuk perguruan tinggi pendidikan guru IPS. Yang masih perlu dikembangkan adalah logika internal atau struktur dari kedua sistim pengetahuan tersebut. Dengan demikian masing-masing memiliki jatidiri konseptual yang unik dan dapat dipahami lebih jernih.

Tentang kedudukan PIPS/PDIPS dalam konteks yang lebih luas tampaknya cukup prospektif. Misalnya, Dahlan (1997) melihat PIPS sebagai upaya strategis pembangunan manusia seutuhnya untuk menghadapi era globalisasi. Sementara itu Tsauri (1997: 1) yang mengutip pemikiran Alfian ketika mengenang tokoh LIPI Profesor Sarwono Prawirohardjo, melihat peranan PIPS dalam perspektif perkembangan ilmu pengetahuan dan teknologi di Indonesia, yang seyogyanya memusatkan perhatian pada upaya pengembangan disiplin yang kuat, ketekunan yang luar biasa, integritas diri yang kukuh, wibawa yang mantap, rasa tanggung jawab yang tinggi, dan pengabdian yang dalam.

Dilihat dari perkembangan pemikiran yang berkembang di Indonesia sampai saat ini pendidikan IPS terpilah dalam dua arah, yakni : Pertama, PIPS untuk dunia persekolahan yang pada dasarnya merupakan penyederhanaan dari ilmu-ilmu sosial, dan humaniora, yang diorganisasikan secara psiko-pedagogis untuk tujuan pendidikan persekolahan; dan kedua, PDIPS untuk perguruan tinggi pendidikan guru IPS yang pada dasarnya merupakan penyeleksian dan pengorganisasian secara ilmiah dan meta psiko-pedagogis dari ilmu-ilmu sosial, humaniora, dan disiplin lain yang relevan, untuk tujuan pendidikan profesioanl guru IPS. PIPS merupakan salah satu konten dalam PDIPS.

PIPS untuk dunia persekolahan terpilah menjadi dua versi atau tradisi akademik-pedagogis yakni: pertama, PIPS dalam tradisi "citizenship transmission" dalam bentuk mata pelajaran Pendidikan Pancasila dan Kewarganegaraan dan Sejarah Indonesia; dan kedua PIPS dalam tradisi social science dalam bentuk mata pelajaran IPS Terpadu untuk SD, dan mata pelajaran IPS Terkonfederasi untuk SLTP, dan IPS Terpisah-pisah untuk SMU. Kedua tradisi PIPS tersebut terikat oleh suatu visi pengembangan manusia Indonesia seutuhnya sebagaimana digariskan dalam GBHN dan UU No. 2/1989 tentang Sistim Pendidikan Nasional.

Perkembangan pemikiran mengenai PIPS ini amat berpengaruh pada pemikiran PDIPS di IKIP/FKIP/STKIP.

Dalam konteks perkembangan pendidikan social studies di Amerika atau "Pendidikan IPS" di Indonesia konsep dan praksis pendidikan demokrasi yang dikemas sebagai citizenship education atau "Pendidikan Kewarganegaraan" berkedudukan sebagai salah satu dimensi dari tujuan, konten dan proses social studies atau "pendidikan IPS". Atau dapat juga dikatakan bahwa pendidikan demokrasi merupakan salah satu subsistem dalam sistem pembelajaran social studies atau 
"pendidikan IPS". Walaupun demikian, subsistem pendidikan demokrasi ini sejak awal perkembangannya, seperti di Amerika sudah menunjukkan keunikannya dan kemandiriannya sebagai program pendidikan yang ditujukan untuk mengembangkan warganegara yang cerdas dan baik. Subsistem ini, sejalan dengan perkembangan konsep dan praksis demokrasi, terus berkembang sebagai suatu bidang kajian dan program pendidikan yang dikenal dengan citizenship education atau civic education, atau untuk Indonesia dikenal dalam label yang berubah-ubah mulai dari Civics, Kewargaan Negara, Pendidikan Kewargaan Negara, Pendidikan Moral Pancasila, Pendidikan Pancasila dan Kewarganegaraan, dan Pendidikan Kewarganegaraan.

Jika dikaji dengan cermat dalam konteks perkembangan social studies ternya citizenship education yang pada dasarnya berintikan pengembangan warganegara agar mampu hidup secara demokratis merupakan bagian yang sangat penting dalam social studies. Hal itu dapat disimak sejak social studies mulai diwacanakan tahun 1937 oleh Edgar Bruce Wesley, yang definisinya tentang social studies dianggap sebagai pilar epistemologis pertama, sampai dengan munculnya paradigma social studies" dari NCSS tahun 1994. Oleh karena itu dapat dikatakan bahwa esensi pendidikan demokrasi sesungguhnya merupakan bagian integral dari social studies Bidang kajian dan program pendidikan demokrasi dalam bentuk kemasan Citizenship education maupun Civic Education atau pendidikan kewarganegaraan ini, kini kelihatan semakin banyak dikembangkan baik di negara demokrasi yang sudah maju maupun negara yang sedang merintis atau meningkatkan diri ke arah itu. Hal itu sejalan dengan berkembangnya proses demokratisasi yang kini telah menjadi gerakan sosial-politik dan sosial-budaya yang mendunia.

\section{Konsep Pendidikan IPS Mengacu pada Undang-Undang No. 20 Tahun 2003}

Dari konsideran Undang-Undang RI No 20 tahun 2003 tentang Sistem Pendidikan Nasional (untuk selanjutnya akan disebut UU Sisdiknas Baru) dengan jelas dapat dipahami mengapa diperlukan adanya UU Sisdiknas Baru itu. Dua pertimbangan yang sangat substansial adalah pertama, UUD 1945 yang mengamanatkan Pemerintah Negara Indonesia yang melindungi segenap bangsa Indonesia dan seluruh tumpah darah Indonesia dan untuk memajukan kesejahteraan umum, mencerdaskan kehidupan bangsa, dan ikut melaksanakan ketertiban dunia yang berdasarkan kemerdekaan, perdamaian abadi dan keadilan sosial; kedua, ...mengamanatkan Pemerintah mengusahakan dan menyelenggarakan satu sistem pendidikan nasional yang meningkatkan keimanan dan ketaqawaan kepada Tuhan Yang Maha Esa serta akhlak mulia dalam rangka mencerdaskan kehidupan bangsa yang diatur dengan undang-undang. Kedua pertimbangan tersebut mengisyaratkan bahwa pendidikan nasional Indonesia harus bersifat mengembangkan insan Indonesia yang baik dan cerdas.

Dalam konteks itu dikonsepsikan bahwa pendidikan itu harus merupakan "usaha sadar dan terencana untuk mewujudkan suasana belajar dan proses pembelajaran agar peserta didik secara aktif mengembangkan potensi dirinya untuk memilki kekuatan spiritual, keagamaan, pengendalian diri, kepribadian,kecerdasan, akhlak mulia, serta keterampilan yang diperlukan dirinya, masyarakat, bangsa, dan negara". Sebagai usaha sadar dan terencana maka yang harus diupayakan adalah membangun suasana belajar dan pembelajaran yang mendidik dan mencerdaskan dengan peserta didik sebagai pusatnya.

Dilihat dari dasarnya, Pendidikan nasional secara konsisten tetap berlandaskan pada "...Pancasila dan Undang-Undang dasar Negara Republik Indonesia tahun 1945" (Pasal 2), dengan sendirinya termasuk dengan seluruh Amandemennya. Sementara itu dalam konteks makro, pendidikan nasional berfungsi"...mengembangkan kemampuan dan membentuk watak serta 
peradaban bangsa yang bermartabat dalam rangka mencerdaskan kehidupan bangsa" (Pasal 3). Dengan kata lain hasil akhir dari pendidikan nasional itu adalah berkembangnya kemampuan individu, terbentuknya watak dan peradaban bangsa yang bermartabat, dan kehidupan bangsa yang cerdas. Untuk mencapai semua itu maka yang harus dilakukan oleh dan dalam dunia pendidikan adalah membangun proses pendidikan yang memungkinkan "... berkembangnya potensi peserta didik agar menjadi manusia yang beriman dan bertaqwa kepada Tuhan Yang Maha Esa, berakhlak mulia, sehat, berilmu, cakap, kreatif, mandiri, dan menjadi warganegara yang demokratis serta bertanggung jawab". (Pasal 3). Guna mewujudkan fungsi dan tujuan pendidikan nasional tersebut, digariskan prinsip-prinsip pendidikan demokratis dan berkeadilan; sistemik, terbuka, dan multi makna; pembudayaan dan pemberdayaan; pemberian keteladanan, pembangunan kemauan, dan pengembangan kreativitas; pengembangan budaya baca, tulis dan hitung; dan pemberdayaan masyarakat. (Pasal 4).

Pada tataran kurikuler, khususnya untuk pendidikan dasar dan menengah ditetapkan pendidikan kewarganegaraan, dan bahan kajian ilmu pengetahuan sosial, bahasa dan seni serta budaya. Secara substantif dan pedagogis kedua bidang kajian tersebut mempunyai hubungan kontributif terhadap semua aspek tujuan pendidikan nasional dengan titik berat pada pengembangan wawasan keilmuan, kecakapan personal dan sosial-kultural, kreativitas, kemandirian, dan karakter warganegara yang demokratis dan bertanggung jawab. Oleh karena itu proses belajar dan pembelajaran secara pedagogis dan sosial kultural menuntut adanya integrasi dari proses pemberdayaan dan pembudayaan dalam bingkai pembelajaran yang mendidik dan mencerdaskan. Dengan demikian maka yang menjadi pilar utama pendidikan kewarganegaraan dan ilmu pengetahuan sosial serta humaniora adalah belajar hidup bermasyarakat (learning to live together) yang ditopang oleh pilar belajar untuk tahu tentang apa, mengapa, dan bagaimana (learning to know) dan pilar belajar untuk berbuat (learning to do), yang pada akhirnya dikristalisasikan dalam pilar belajar untuk hidup menjadi manusia yang utuh (learning to be).

Dari analisis terhadap substansi dasar, fungsi, dan tujuan pendidikan nasional dan landasan serta subsatansi kurikuler sebagaimana tertuang dalam UU Sisdiknas Baru itu, maka paradigma belajar dan pembelajaran pendidikan sosial dan humaniora yang perlu dikembangkan untuk pendidikan dasar dan menengah adalah paradigma integrated social studies atau studi sosial/ kajian sosial terpadu sebagaimana digagas dan ditawarkan oleh Hartonian (1992) sebagai integrated system of knowledge.

\section{Paradigma Pendidikan IPS untuk Pendidikan Dasar dan Menengah.}

Sebagaimana ditegaskan oleh Hartonian (1992) pendidikan IPS seyogyanya mengacu pada konsep integrated knowledge system atau sistem pengetahuan yang terpadu. Paradigma ini dilandasi oleh pertimbangan psiko-sosial-pedagogis bahwa hakikat dan kenyataan kehidupan manusia yang bersifat terpadu, dan oleh karenanya pendidikan sosial seyogyanya dirancang demikian rupa seperti keterpaduan manusia dengan seluruh konteks kehidupannya. Bila tidak demikian maka pendidikan sosial tidak akan mampu membekali dan memfasilitasi peserta didik untuk hidup dengan cerdas dan baik di dalam dan melalui kehidupan masyarakat. Lebih dari itu perlu dipahami bahwa khususnya untuk sekolah dasar yang menurut Piaget (1970) peserta didiknya itu berada pada tahap berpikir kongkrit atau concrete operation menuju berpikir formal atau formal operation, maka pembelajaran dengan pendekatan terpadu sangatlah penting. 
Secara teoritik terdapat sejumlah model pengembangan pengalaman belajar atau learning experiences IPS terpadu yang secara umum dapat dikelompokkan kedalam beberapa pendekatan (Dufty;1970, Winataputra,1978) sebagai berikut.

- Pendekatan Struktural atau structural approach. Pendekatan ini berpijak pada konsep atau generalisasi yang diturunkan dari struktur keilmuan disiplin ilmu-ilmu sosial (georafi, sejarah, sosiologi, antropologi, ekonomi, psikologi, hukum) dengan tujuan agar peserta didik memahami konsep suatu disiplin dengan cara yang lebih bermakna (meaningful). Termasuk ke dalam pendekatan ini model pembelajaran konsep atau generalisasi secara spiral atau spiral development of concept or generalization yang dikembangkan oleh Hilda Taba (1967), dan model "roda kegiatan dasar manusia" atau wheel of basic human activities yang dikembangkan oleh Paul R.Hanna (1970). Konsep terpadu yang dikembangkan Taba adalah perubahan budaya, perbedaan, dan saling ketergantungan (cultural change, difference, interdependence). Sementara yang dikembangkan oleh Hanna adalah konsep-konsep produksi, perdagangan dan konsumsi; transportasi; komunikasi; pendidikan; rekreasi; proteksi dan konsenvasi; organisasi dan pemerintahan; ekspresi kebutuhan estetika dan spiritual; penciptaan alat dan teknik baru. Baik konsep-konsep model Taba maupun model Hanna dikembangkan secara spiral untuk berbagai tingkat atau kelas (1 s/d 6) dengan menyertakan konteks kehidupan dari lingkup keluarga kampung, desa, kecamatan, kabupaten/kota, propinsi, dan sampai ke lingkup negara (expanding community approach).

- Pendekatan Fungsional atau functional or problem approach. Pendekatan ini berorientasi pada pemecahan masalah-masalah kehidupan masyarakat dengan tujuan agar peserta didik mampu menggunakan wawasannya secara kritis untuk memecahkan masalah sosial. Model pendekatan fungsional yang sangat terkenal adalah model Bruner's "Man: A Course of Study" (Suatu Kajian Tentang Manusia) untuk menjawab antara lain pertanyaan Apa yang membuat manusia itu bersifat manusiawi (bermasyarakat, berbudaya, beradab)? Masalah lain yang dapat dijadikan pusat kajian adalah masalah sosial kontemporer seperti korupsi, masalah yang paling berarti dalam masyarakat misalnya kemiskinan; dan masalah nilai misalnya kebohongan publik.

- Pendekatan Antar Bidang atau interfield approach. Pendekatan ini memusatkan perhatian pada isu-isu yang besar yang dapat dilihat dari berbagai sudut pandang disiplin ilmu sosial dan humaniora dengan tujuan agar peserta didik mampu berpikir secara interdisipliner (interdsciplinary).Termasuk ke dalam pendekaatan ini adalah model kegiatan inti dalam masyarakat misalnya pembangunan; perubahan kebudayaan misalnya Renaissance (Kebangkitan peradaban); model kajian wilayah misalnya kajian masyarakat di daerah Batu Malang, Puncak Bogor; Riau lautan dll dan kajian suatu peristiwa besar misalnya Proklamasi kemerdekaan Indonesia 17 Agustus 1945.

Setiap model pembelajaran IPS terpadu dalam kadarnya yang berbeda mengusung berbagai misi psiko-pedagogis konstruktivisme, ko-konstruktivisme, kontekstualisme, sosialisasi, enkulturasi. Misi tersebut menekankan bahwa proses belajar IPS bertujuan memfasilitasi peserta didik untuk membangun pengetahuan, beradaptasi dengan lingkungan, membudayakan dirinya dan lingkungannya, mendewasakan diri dalam lingkungannya. Oleh karena itu pembelajaran IPS seyogyanya dikembangkan menjadi pembelajaran IPS yang kuat atau powerful social studis (NCSS: 2000) yang secara konseptual ditandai oleh prinsip-prinsip bermakna, integratif, berbasis-nilai, 
menantang, dan mengaktifkan (meaningful, integrative, values-based, challenging, active). Sementara itu bila kita mau melakukan benchmarking terhadap model lain, model History-Social Science California (2001) dapat memberi inspirasi baru dalam mereposisi dan mereorganisasi kurikulum dan pembelajaran PKn dan IPS di Indonesia ke depan. Di dalam model tersebut dikemukakan tiga strands (cabang) tujuan, yakni democratic understanding and civic values, knowledge and cultural understanding, dan skills attainment and social participation (California Dept of Education, 2001:10-19). Yang termasuk dalam tujuan pengembangan democratic understanding and civic values adalah national identity, constitutional heritage and civic values, rights, and responsibilities. Sementara itu yang tercakup dalam tujuan pengembangan knowledge and cultural understanding adalah historical literacy, ethical literacy, cultural literacy, geographic literacy, economic literacy, dan sociopotical literacy. Sedangkan yang termasuk dalam skills attainment and social participation adalah basic study skills, critical thinking skills, dan participation skills.

\section{Tantangan IPS ke PKn ke depan}

Saat ini dan ke depan pembelajaran PKn dan IPS menghadapi berbagai tantangan yang sekaligus merupakan peluang bagi pendidik dan pendidik guru PKn dan IPS untuk secara sinergistik membangun kekuatan intelektual dan pedagogis. Diantara berbagai tantangan dan peluang itu tercakup dalam konsepsi dan atau fenomena paradoksal antara lain sebagai berikut.

* Kecenderungan masyarakat mendunia versus pengokohan negara kebangsaan;

* Pengokohan persatuan dan kesatuan bangsa versus otonomi daerah yang luas pada tingkat kabupaten/kota;

* Pengokohan persatuan dan kesatuan bangsa versus polarisasi kehidupan politik dengan sistem multi partai;

* Perkembangan ekonomi pasar versus ekonomi kerakyatan;

* Perkembangan nilai-nilai kontemporer versus nilai-nilai tradisional;

* Arus urbanisasi akibat pertumbuhan kota versus ketertinggalan masyarakat perdesaan

* Tradisi kurikulum berbasis materi disiplin ilmu versus kurikulum berbasis kompetensi versus kurikulum beorientasi kehidupan

* Tradisi pembelajaran ekspository berbasis bahan cetakan versus trend pembelajaran inkuiri berbasis aneka sumber/ jaringan;

* Penilaian melalui pengetesan versus penilaian berbasis portofolio;

* Figur guru sebagai penyembur pengetahuan (disseminator of knowledge) versus figur guru sebagai pengarah dan fasilitator belajar (director /facilitator of learning);

* Pendidikan guru IPS terkotak-kotak versus pendidikan guru IPS terpadu.

Situasi paradoksal tersebut mengisyaratkan bagaimana seharusnya para pakar dan praktisi bersama-sama mereposisi dan selanjutnya merancang dan mengembangkan kurikulum dan pembelajatran pembelajaran PKn dan IPS yang adaptif terhadap berbagai dimensi perubahan kontekstual baik dalam kancah global, nasional, maupun lokal. Dalam kaitan dengan hal tersebut sekali lagi kita maknai peringatan dari Hartonian (1992) yang dapat kita ungkapkan ketahuilah bahwa 
kehidupan ini bersifat terpadu satu sama lain saling tergantung tak ada yang sungguh berdiri sendiri. Kecuali kita merancang dan mengembangkan PKn dan IPS seperti hakikat dan realita kehidupan itu begitu rupa, maka sesungguhnya kita sudah mengorbankan peserta didik anak bangsa calon pemimpin di masa depan menghadapi resiko besar. Dengan kata lain paradigma pembelajara PKn dan IPS berbasis kehidupan, khususnya untuk pendidikan dasar dan menengah adalah suatu keniscayaan, sesuatu yang seyogyanya kita kembangkan guna meningkatakan kualitas proses dan hasil belajar PKn dan IPS dalam konteks pendidikan dasar dan menengah.

\section{REFERENSI}

Barr, R.D., Barth, J. L., \& Shermis, S.S. (1977). Defining the social studies. Virginia: National Council for The Social Studies.

Barr, R. D., Barth, J. L., \& Shermis, S.S. (1978). The nature of the social studies. Palm spring: An ETS Pablication.

California Department of Education (2001). History-social science framework for California public schools kindergarten through grade twelve. Sacramento.

Dahlan, M. A. (1997). Pendidikan IPS sebagai upaya strategis pembangunan manusia seutuhnya untuk menghadapi era globalisasi. Jakarta: Panitia saresehan dan forum komunikasi pimpinan FPIPS-JPIPS se Indonesia VIII.

Departemen P dan K (1968a). Kurikulum sekolah dasar. Jakarta.

Dufty, D. G. (1970). Designing integrated course, dalam teaching about society. Sydney: Rigby.

Hartoonian, H. M. (1992). The social studies and project 2061: An opportunities for harmony, dalam The social studies, 83(4), 160-163.

NCSS (1989). Charting a course: Social studies for the $21^{\text {st }}$ century. Washington: National commission on social studies in the schools.

NCSS (1992). In search of a scope and sequence for social studies dalam social education, 48(4), 249-264.

NCSS (1994). Curriculum standars for social studies: Expectation of excellence. Washington.

PPSP IKIP Bandung (1973a). Program kurikulum studi sosial sekolah dasar pembangunan. Bandung.

PPSP IKIP Bandung (1973b). Program kurikulum studi sosial sekolah menengah pembangunan. Bandung.

Sanusi, A. (1998a). Pendidikan alternatif: Menyentuh azas dasar persoalan pendidikan dan kemasyarakatan. Bandung: PT. Grafindo media pratama.

Soemantri, S. (1998). Esensi dan kecenderungan pendidikan politik dan hukum kenegaraan memasuki era abad 21.

Somantri, N. (1969). Pelajaran kewargaan negara di sekolah. Bandung: IKIP Bandung.

Stanley, W. B. (1983). Review of research in social studies education: 1976-1983. Washington: NCSS.

Tsauri,H.S. (1997). Pendidikan ilmu pengetahuan sosial dan manusia Indonesia seutuhnya dalam perspektif perkembangan illmu pengetahuan dan teknologi di Indonesia. Jakarta: Panitia seminar dan forum komunikasi VIII pimpinan FPIPS-IKIP dan JPIPS-FKIP se Indonesia.

Welton,D.A. \& Mallan,J.T. (1988). Children and their world: Strategies for teaching social studies. Boston: Houghton Mifflin Co.

Winataputra,U.S., (1978). A pilot study of the implementation of the SMA PMP curriculum in Bandung Area. Sydney: Macquarie University (MA.Thesis). 